\title{
An empirical study on Mobile Advertisement
}

\author{
Muhammad Jahanzaib \\ Student, Department of Management Sciences \\ The Islamia University of Bahawalpur
}

Mujeeb Sukheera

Student, Department of Management Sciences

The Islamia University of Bahawalpur

\section{Umair Razzaq}

Student, Department of Management Sciences

The Islamia University of Bahawalpur

\section{Amir Zameer}

Student, Department of Management Sciences

The Islamia University of Bahawalpur

Accepted: September 22, 2014

Doi:10.5296/ jpag.v4i3.6679 URL: http://dx.doi.org/10.5296/ jpag.v4i3.6679

\begin{abstract}
The rationale of our study is the practices of mobile phones for commercial in organize to save the time and price. We consider that in future mobile advertisement will be the best way to talk and advertised the company's produce directly to target market or target consumer. We have used suggestive study skill to judge the suitability of mobile phone as a means of advertisement. So extreme that we have taken 200 samples of students and used regression analysis skill to compute the effectiveness of our variables influence mobile advertisement. We have found all of our variables as well as institutional purchase intention, advertisement value, permission, attitude toward mobile advertisement are having important and optimistic relationship with mobile advertisement. These variables are main variable of our subject and also these are special for mobile advertisement. All the hypothesis are well support no one is
\end{abstract}


useless. We associate that the relation between these variable with mobile advertisement are positive. We conclude the result after realistic study that mobile advertisement plays a major responsibility to move any information as regards news, information, horoscope, instructions and any information to the people.

Keywords: Attitude towards mobile advertisement, Permission, Purchase intension, Advertising value

\section{Introduction}

This study aims to survey the factors that influence attitude toward mobile advertising and make up a theoretical model to check the influence of three previous factors (purchase intention, advertising value and permission) on customer attitude towards advertisement. The advertising industry universal is experience terrific changes arguing that advertising is the essential element for new life. Management involvement in the advertising industry to an assured amount has keeping pace the content of the advertising message, and consequently this produced sure impacts on the creation of customer attitude towards advertising. The main source is that to make customer policy to agree for mobile, as for this stander advertising are up till fully understand. Specially, there are two mainly serious determinants of mobile advertising for customer, permissions determined by the target listeners' and incentive provided, are included as handling factors between the investigational subjects process and are explore in the terms of their effects on customer attitudinal and behavioral responses of customer, i.e., promotion by some previous phenomenon. The level of interest in which mobile message by recipients have with the message satisfied as well as their past practice with the mobile means is fully.

Being a utility-based communication tool is just have mobile phones surpass and a fashion item, a position sign, and a way for individual's person have now served as to communicate themselves. For new advertising medium it is require understanding the SMS. The maximum of mobile phones users are transfer and receiving text by using mobile short message service (SMS) transmission. The wireless media (such as pagers and cellular phones, mobile telephone, two-way radios, wireless networking system, child cheat monitors, GPS-based locators, maps and personal digital assistants) habit of inter active to broadcast advertising messages to customers in form of time and location sensitive, overall purpose of these information is modified to promote goods .Also with using mobile devices, mobile advertising provides a new channel to consumer for transmitting marketing messages.

This study discuses the variable of Permission, Advertising value, Purchase intention, Attitude toward mobile advertising. Permission means sending mobile advertisements message depends on the readiness of the consumer in case he/she allow the company to send him/her advertisement message otherwise company will not send him/her advertisement message. Other variable is Purchase intention, which means readiness of a consumer to buy a particular product that is backed by various determinants like attitude towards the product and figure of its producer and also by the major determinants of need and purchasing power. 
Attitude toward Mobile Advertising means "A perceived thinking of human beings". Advertising value is calculate of advertising efficiency and "may provide as an index of customer satisfaction with the communication products of organizations" in excess of time, the mobile industry has moved from text messages to icons and picture messages to photographs. The application is improved messaging services (EMS) and multimedia messaging with the importance of technology core of fresh services and application

The design of mobile advertisements should be balance to support the commercial goals and the user goals. It is maybe overstatement is not to state that the handset is the most ever-present unique item in the world. Additional of new years, the cellular phone has become extra feature with also the increasingly small product. The main purpose of a mobile phone is to permit users to talk to each other, mobile phone services such as short messaging services (SMS, or text messaging in language) have newly adult very quickly. In the market customers provide the personal information and data, so that the mobile marketing can put into apply for full benefits. In many markets The Internet-enabled cellular phone has quickly proliferated. In 1998 firstly release WAP (wireless application protocol), firm began location-sensitive and send news alerts ads to mobile users. Due to the use of short message services (SMS) and multimedia messaging services is the personal nature of the mobile phone because purpose of marketing has significantly increased in numerous parts of the world.

As a part of an incorporated marketing communication strategy (IMC), there are some agencies and marketers who are making a remarkable improvement. The mobile advertising includes contribution of customer in SMS advertisements. The mobile phone is the only source to communicate directly to target consumer because it is one and only personal item in the world.

As compared to prior years, many companies at a high speed gaining the value of mobile phones in business activities such as sales promotion, target market communication etc. Enlargement in mobile market, adoption of modern technology, techniques and their implications has cleared a lot new different kind of opportunities for advertising companies to help them in sales promotions and advertisements. There has been drawn a stronger and better focus on these elements is necessary to get better effectiveness in SMS advertising campaigns. The research tries to make a specific concept and test factors that manipulate the aspect of mobile advertising promotion, with necessary importance on push advertising via text messaging. The ease of use and perceived usefulness of the service is not much influence by the short message service as much.

The study about mobile advertising emphasizes about individual acceptance of mobile SMS alerts is a meaning results the attitude toward the use of mobile SMS service. That is also factor of perceived acceptance, subjective norm, usefulness and intrusiveness. Empirical data provide that data which support our considerate, to test and develop the basic model of consumer for agree to permission to receive SMS advertisement. The increase and junction of distribution of mobile computing, telecommunications and networking has significant create commercial opportunity. So we can appreciate that this is the sensitive issue of sending the 
advertisement messages without the permission of the consumer. These mobile marketing activities were integrated into the study because they were careful to be signifying the level of customer participation in mobile marketing.

\section{Literature Review}

Before we build up our hypotheses, we need to simplify the factors influencing the mobile advertisement. So that's why we have carefully review the prior literature which is linked to mobile advertising markets. Based on present literature determinants such as permission, purchase intention, advertising show strong relationship with attitude towards mobile advertising

\section{Attitude toward Mobile Advertising:}

Attitude toward Mobile advertising, in (1967, p.53) Fishbein define the attitude as "human beings learned a tendency". As say that tendency learned tendency human behavior. Kotler (2000) more attitude of individual personal valuation is elaborates emotion feeling attached and act on tendency toward some things. In dealing to the advertising industry, Bauer and Greyser(1968). As the audience behavior the obtaining of sight of attitude toward advertising industry. Audience behavior towards the advertising can be indicated through consumer's favorable or unfavorable reaction towards a particular advertisement (Mackenzie and lutz, 1989). According to Mehta (2000), consumer's attitude towards advertising is one of the prominent indicator of advertising effectiveness because consumer's capacity towards the advertising the reflected in their judgment (Mackenmie and Lutz, 1989).

The study of attitude toward advertising in common may be especially important because it influences attitudes toward a exact ad, an important antecedent of brand attitudes (e.g., Alwitt and Prebake 1992; Mackenzie and Lutz 1989). Tsang, Ho, and Liang (2004) also found that consumers have usually negative attitudes toward mobile advertising except they have specifically consented to receive the advertising messages. Thus, it is possible that attitudes toward specific mobile advertisements are influenced by attitudes toward advertising using cellular phones in common.

As a part of a academic tendency human behavior, Kotler (2000) further explains that the attitude is the personal feelings of emotions or attached with any achievement about some idea or object. Bauer and Greyser, (1968) considering the mobile marketing industry, attitude towards advertising is the audience behavior towards the advertising.

\section{Purchase Intention:}

"The possibility that a consumer will buy a detailed product due to the dealings of his/her need for it, perception and attitude towards the product which is produced by company". It is also defined as: A perception or antecedent of purchasing is a specific product or service in the near future. Purchase intention means readiness of a consumer to buy a particular product that is backed by various determinants like attitude towards the product and image of its producer and also by the primary determinants of need and purchasing power. 
H1: There is positive relationship between purchase intention and attitude toward mobile advertising.

\section{Advertising Value}

Standards are the basis of actions, attitudes, and judgments related to advertising as well as other aspects of social life (Beatty et al. 1985). Advertising value is a measure of advertising effectiveness and "may serve as an index of customer satisfaction with the communication products of organizations" (Ducoffe 1995, p 1). A value is a "faith about some desirable end-state that transcends specific situations and guides selection of behavior" (Schwartz and Bilsky 1987). An attitude toward advertising is defined as a consumer's "learned tendency to reply in a constantly favorable or unfavorable way toward advertising in general" (MacKenzie and Lutz 1989, p 54) and has a main impact on their behavior (Iacobucci and Churchill 2010). Exchange, the central concept in marketing, involves the passing of value to each party (Houston and Gassenheimer 1987). An advertising message can be viewed as a latent communication exchange between advertiser and consumer (Ducoffe 1995). For exchanges to be effective, it is important to consider both parties' perspectives. The advertiser's aim is to influence the consumer's attitude about whether to purchase. Therefore, the value of any advertisement is evaluate against this norm (Ducoffe 1996). To the consumer, a successful exchange is judge by whether the advertising value itself can be considered to satisfy their expectations. With the great advances in communication technologies that are expected, consumers may slowly pay for advertising they favor and monitor out the rest (Mayer 1991). One would expect that advertising that lacks value is likely to have a negative effect that will add to the formation of negative consumer attitudes toward advertising (Ducoffe 1996). Rotating this argument around, we thus conclude that a high perceived value of m-advertising will reflect positively on a consumer's attitude toward m-advertising.

H2: Advertising value is positively associated with attitude toward mobile advertising.

\section{Permission}

In the beginning of permission the two way of mobile communication between the mobile marketer and customer. In simple words about say that permission may be unstated as the "dynamic boundary produced by the combination of one's personal preferences" (Barnes and Scornavacca, 2004, p. 133).In other preference which is included, for example in the term of time message location and information is personalization messages content. In shortly, without the precise permission from the customer it is not possible to take out mobile marketing (Kautonen et al., 2007). To send marketing message by electronic channel is just Seeking a customer's past such as mobile is called opt-in mobile marketing. Attitude towards advertisement is an important factor for the purpose of getting information about it. The permission which is based on advertisement, consumer allows the marketer to have a complete knowledge about mobile advertisement. The part which disturbs the consumer is that there is a great difference between permission based advertising and a traditional 


\section{Macrothink}

advertising. Consumers are provided with information with proper feedback about advertising is dealt in this sort of advertising. This point of view states that the advertising based on permission allows us to ease the effect which focuses on target group of customers, willing participant are involved in the market advertisement. Past results have a conclusion that the permission based on advertisement does not go spoiled. It is an important issue about sending advertisement messages is getting information from the customer. Personal information about the customer can be get and the danger about the reducing the customer size can be minimized.

The hypothesis determined in this direction is as follows:

H3: There is a strong positive relationship between permission and attitude towards mobile advertisements.

\section{Research Model:}

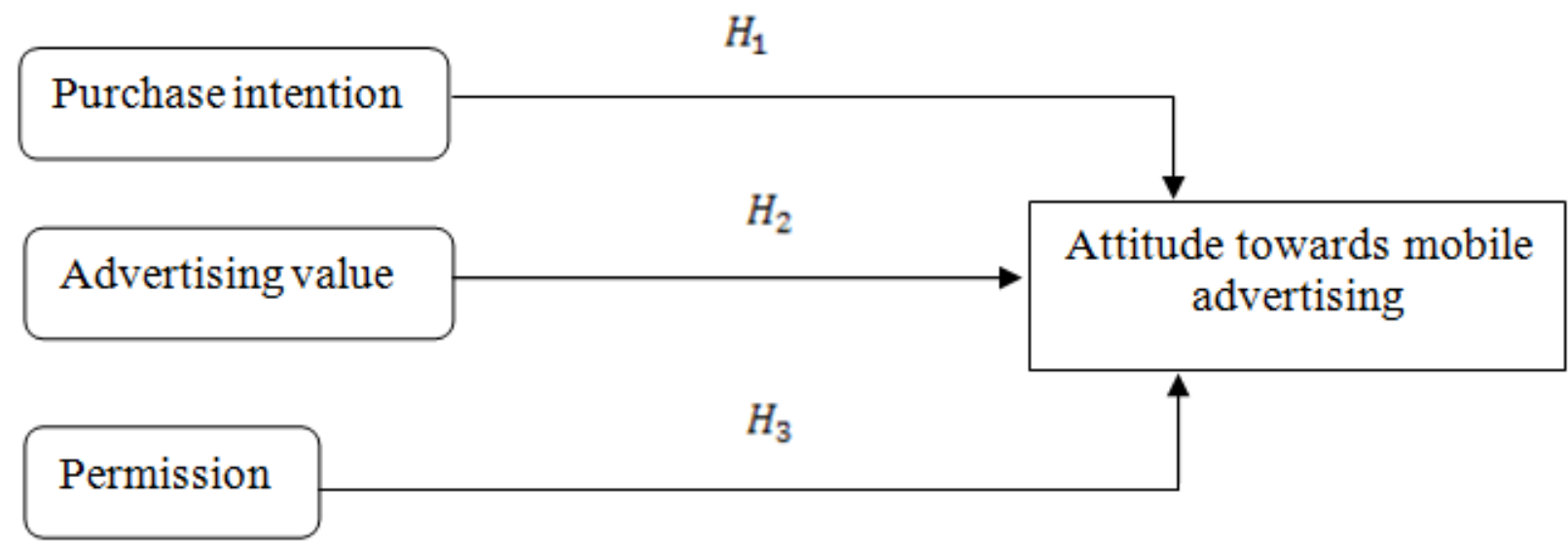

\section{Research Methodology}

The nature of the research in this paper is descriptive. This research indicates about telling any fact which has been get from previous researches. These of those sort of research which give us information about a certain topic in expressive way and does not includes any judgment or decision making (Creswell, 1994). The reasons behind this type of research are to justify about the hypotheses which are being considered. Present and past situation are being discussed in these sort of descriptive research i.e quality of life in a society (Kumar, 2005). 


\section{Sample/Data:}

There is a need to understand the situation about the data that how can we collect about acceptance of mobile advertisement. The parameter is chosen to take about 200 respondents with self determined question. The whole research was conducted in Pakistan (Bahawalpur). Non-probability technique is being used that is convenience sampling. In this type of sampling, large number of completed survey is conducted (Lym, 2010). We select sample members from different department of IUB. Two main clusters will target to collect the sample data similar to students and faculty members. The selection of students and working professionals are based on the previous results of the studies on mobile advertisements.

\section{Instrument \& Scales:}

The survey instrument of the present study address two major process: First is to analyze the relationship of different variables in the acceptance of mobile advertisement. Second collect information about the different characteristics of the respondents that can be used to understand the variations in different categories. This survey instrument contains two sections. Section 1 includes different personal and demographic variables. This section will obtain the respondent's information about gender, age, income, education, status, the name of network he/she is using. Section 2 includes the latent variables that are important in the current study. These variables include attitude towards mobile advertisement, purchase intention, advertising value and permission. This section of the study is developed based on the prior time literature and already used questionnaires (Table-1). The scales of the study were adopted from the prior literature and published studies. The first variable is attitude toward mobile advertising having three items, which taken from Alwitt and Prabhacker's (1994). Second variable is purchase intention which having just two item and it also taken from (Fishbein and Ajzen, 1975). Third is advertising value which having three variable taken from value were derived from Ducoffe's (1996)and from last is permission, its having three items taken from Bauer et al., 2005; Nysveen et al., 2005; Tsang, Ho, and Liang, 2004.

Table 1. Scale of the Model:

\begin{tabular}{|l|l|l|l|}
\hline NO. & \multicolumn{1}{|c|}{ Variables } & \multicolumn{1}{|c|}{ Items } & References \\
\hline 01 & $\begin{array}{l}\text { Attitude towards } \\
\text { Mobile } \\
\text { Advertising }\end{array}$ & $\begin{array}{l}\text { 1) SMS advertising helps raise our } \\
\text { standard of living } \\
\text { 2) SMS helps me to find products that } \\
\text { match my personality and interests } \\
\text { 3) SMS Advertising helps me buy the best } \\
\text { brand for a given price }\end{array}$ & $\begin{array}{l}\text { Alwitt Prabhacker's (1994) } \\
\text { and }\end{array}$ \\
\hline
\end{tabular}




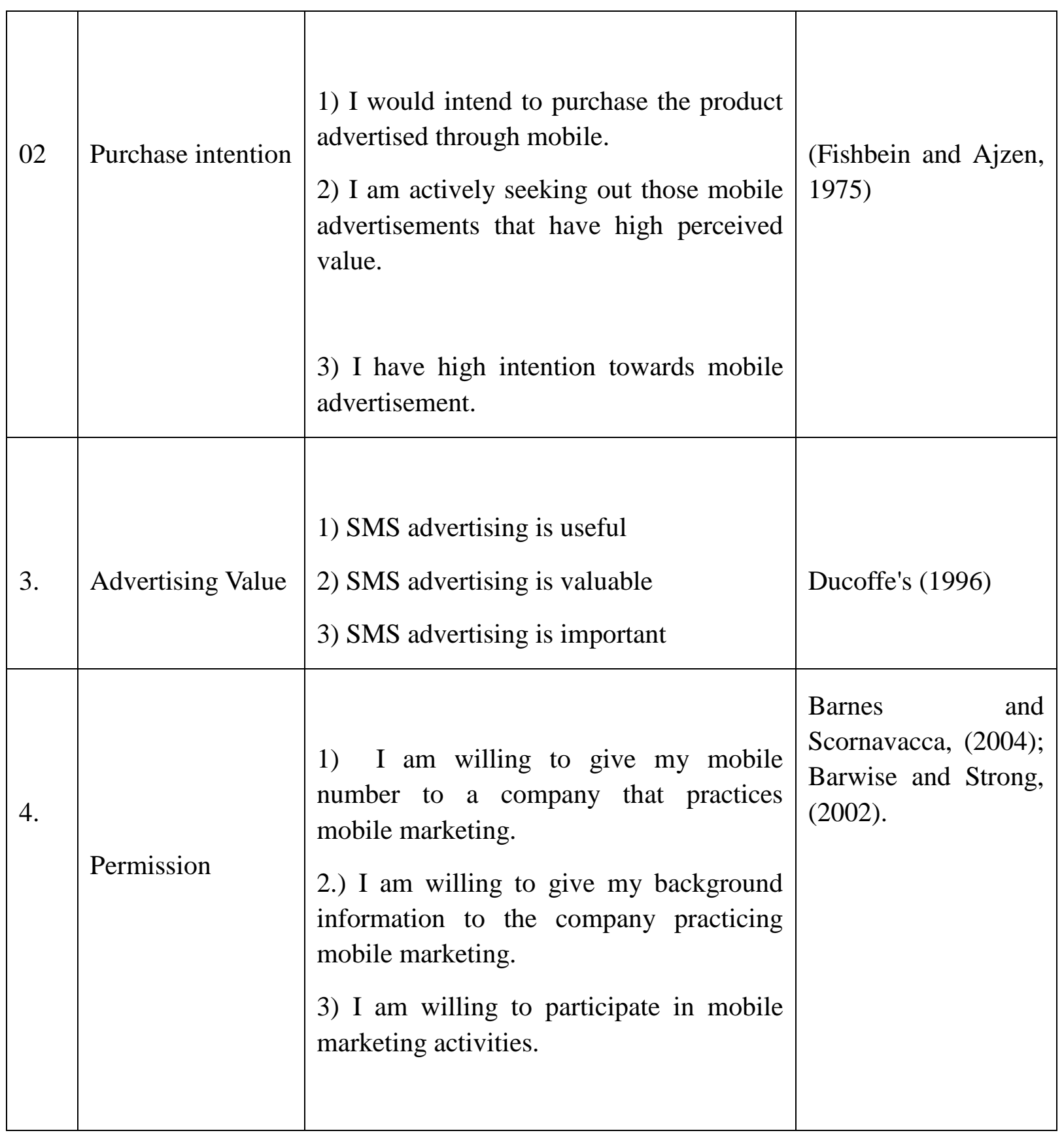

\section{Regression Analysis:}

The questionnaire was distributed among 150 respondents in Abbasia campus and Bagdad ul jadid campus of The Islamia University of Bahawalpur. These respondents are selected based on the criteria above mentioned. Before giving the questionnaire, the purpose of study and questions were explained to the respondents so they can easily fill the questionnaire with relevant responses. A total of 150 questionnaires were selected and rest of the questionnaires was not included in the further analysis due to incomplete or invalid responses. After collecting the completed questionnaire, these questionnaires were coded and entered into SPSS sheet for regression analysis. 


\section{Macrothink}

\section{Reliability analysis:}

Overall Cronbach's alpha of our variable in our study are more than acceptable and recommended value 0.50 by Nunnally, (1970) and 0.60 by Moss et al. (1998). This shows that all the 18 items were reliable and suitable to measure the opinions of consumers towards mobile advertisements.

Table2 : Reliability of Measurement Instrument

\begin{tabular}{|l|c|c|}
\hline \multicolumn{1}{|c|}{ Scales } & items & Cronbach alpha \\
\hline $\begin{array}{l}\text { Attitude Toward } \\
\text { Advertising }\end{array}$ & $\mathbf{3}$ & 0.67 \\
Purchase intention & & \\
Advertising Value & $\mathbf{2}$ & 0.57 \\
Permission & $\mathbf{3}$ & 0.59 \\
& $\mathbf{3}$ & 0.64 \\
\hline
\end{tabular}

\section{Result and analysis:}

\section{Profile of the Respondents}

Personal and demographic information such as gender, age, income, education level, status and the network being used by the respondents are given in following Table-3.

Table No3:

\begin{tabular}{|l|l|l|l|}
\hline Variable & Category & Frequency & Percentage \\
\hline & & & \\
Gender & Male & 78 & \\
& Female & 74 & 48.3 \\
\hline
\end{tabular}




\begin{tabular}{|c|c|c|c|}
\hline Age & $\begin{array}{l}\text { 15-20 years } \\
21-25 \text { years } \\
26-30 \text { years } \\
31-35 \text { years } \\
36-40 \text { yrs } \\
\text { Above } 41 \text { years }\end{array}$ & $\begin{array}{r}15 \\
85 \\
38 \\
10 \\
3 \\
1\end{array}$ & $\begin{array}{l}9.9 \\
55.5 \\
25.0 \\
6.6 \\
2.0 \\
0.7\end{array}$ \\
\hline Education & $\begin{array}{l}\text { Matriculation } \\
\text { Intermediate } \\
\text { Bachelor } \\
\text { Masters } \\
\text { MS/M.Phil } \\
\text { PHD }\end{array}$ & $\begin{array}{r}0 \\
5 \\
58 \\
76 \\
11 \\
2\end{array}$ & $\begin{array}{r}0 \\
3.3 \\
38.2 \\
50.0 \\
7.2 \\
1.3\end{array}$ \\
\hline Monthly Income(Rs) & $\begin{array}{l}\text { Below } 15000 \\
15000-25000 \\
25000-35000 \\
35000-45000 \\
45000-55000 \\
\text { Above } 55000\end{array}$ & $\begin{array}{r}58 \\
59 \\
18 \\
4 \\
12 \\
1\end{array}$ & $\begin{array}{r}38.2 \\
38.8 \\
11.8 \\
2.6 \\
7.9 \\
0.7\end{array}$ \\
\hline
\end{tabular}




\begin{tabular}{|l|l|c|c|}
\hline \multirow{5}{*}{ Status } & Student & 92 & \\
& Employed & 30 & 60.5 \\
& Businessman & 23 & 19.7 \\
& Unemployed & 4 & 15.1 \\
& Housewife & 3 & 2.6 \\
& & & 2.0 \\
\hline
\end{tabular}

\section{HYPOTHESIS TESTING}

\section{Purchase intention \& Attitude toward Mobile Advertisement}

According to the results of the study, the variable Purchase intention has a positive significant relationship with Attitude toward Mobile Advertising. Specifically, purchase intention and Attitude toward mobile advertising have positive relationship with $(\boldsymbol{\beta}=\mathbf{0 . 1 4 0})$ and $(\mathbf{p}<$ 0.0001). That means purchase intention contribute more than $28 \%$ towards Attitude toward mobile advertising.

\section{Advertising Value \& Attitude toward Mobile Advertisement}

The regression results of the study confirm the significant positive relationship between Advertising Value and Attitude toward mobile advertising with $(\boldsymbol{\beta}=\mathbf{0} . \mathbf{1 8 2})$ and $(\mathbf{p}<\mathbf{0 . 0 0 0 1})$. According to these results advertising value contributes more than $36 \%$ to Attitude toward mobile advertising.

\section{Permission \& Attitude toward Mobile Advertisement}

Regression analysis of the mobile advertisement model shows that attitude advertising value has significant and positive relationship with Attitude toward mobile advertising having ( $\boldsymbol{\beta}=$ 0. 181) and (p < 0.0001). That means Advertising value contributes more than $36 \%$ toward mobile advertising.

\section{Purchase intention, Advertising value, Permission}

Regression estimate results shows that there is positive relationship between purchase intention, advertising value and permission with attitude toward mobile advertising with ( $\boldsymbol{\beta}$ $=.160)$ and $(\mathbf{p}<0.0001)$. 
Table 4. Regression Results

\section{Coefficients}

\begin{tabular}{|c|c|c|c|c|c|c|}
\hline \multirow{2}{*}{\multicolumn{2}{|c|}{ Model }} & \multicolumn{2}{|c|}{$\begin{array}{l}\text { Unstandardized } \\
\text { Coefficients }\end{array}$} & \multirow{2}{*}{$\begin{array}{l}\text { Standardized } \\
\text { Coefficients }\end{array}$} & \multirow[b]{2}{*}{$\mathrm{t}$} & \multirow[b]{2}{*}{ Sig. } \\
\hline & & B & Std. Error & & & \\
\hline \multirow[t]{4}{*}{1} & (Constant) & 1.157 & .261 & & 4.438 & .000 \\
\hline & PurIntent_Final & .124 & .071 & .140 & 1.939 & .014 \\
\hline & $\begin{array}{l}\text { AdverValue_Fin } \\
\text { al }\end{array}$ & .098 & .097 & .182 & 2.007 & .015 \\
\hline & $\begin{array}{l}\text { Permission_Fina } \\
\text { l }\end{array}$ & .186 & .086 & .181 & 2.174 & .031 \\
\hline
\end{tabular}

Figure 2:

Structural Model results

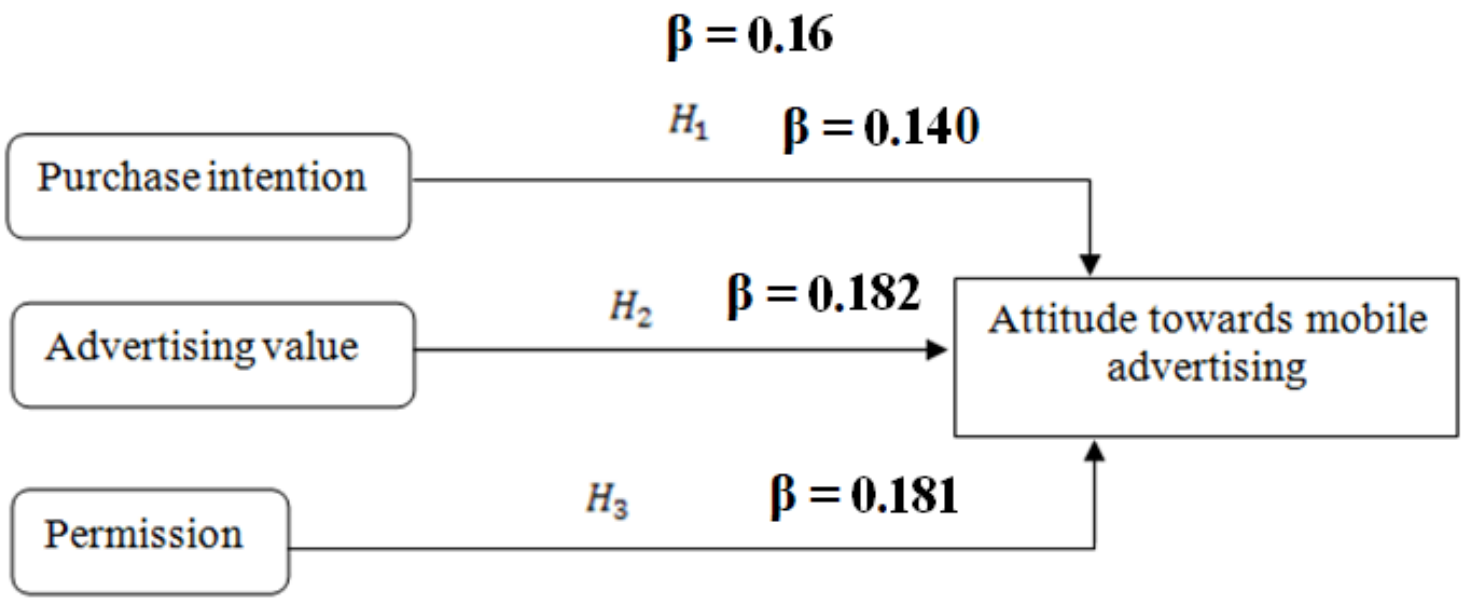




\section{Discussion}

Our research was conducted to conceptualize the way in which Purchase intention, advertising value and permission affect the Attitude toward mobile advertising, than impact of attitude toward mobile advertising on consumer's will to give his/her personal information and allowing them to use it. In the context mobile advertising, we have developed a conceptual modal on the basis of literature review, and tested with data collected from campuses of Islamia University of Bahawalpur. We found that Attitude toward mobile advertising, purchase intention, advertising value and permission are the main factors influencing the willingness of consumer to participate in mobile marketing context.

According to the results of the study, the impact of purchase intention is significant and positive on Attitude toward mobile advertising. Specifically, purchase intention and attitude toward mobile advertising are linked with $(\beta=0.140)$ and $(\mathrm{p}<0.0001)$. That means purchase intention contribute more than $28 \%$ towards attitude toward mobile advertisement. There is a significant positive relationship between advertising value and Attitude toward mobile advertising with $(\beta=0.182)$ and $(p<0.0001)$. According to these results advertising value contributes more than $36 \%$ to attitude toward mobile advertisement. Regression analysis of the mobile advertisement model shows that permission has a significant positive relationship with Attitude toward mobile advertising with $(\beta=0.181)$ and $(\mathrm{p}<0.0001)$. That means permission contributes more than $36 \%$ towards attitude toward mobile advertising.

\section{Refrences:}

Fishbein (1967, p.53) defines attitude as "a learned predisposition of human beings"

Kotler (2000) further elaborates attitude as an individual personal evaluation, emotional feeling attached and action tendency toward some objects or idea

Bauer and Greyser (1968) take the view of attitude towards advertising as the audience behavior towards the advertising

MacKenzie and Lutz (1989) Audience behavior towards the advertising can be indicated through consumers' favorable or unfavorable response towards a particular advertisement.

Mehta (2000) consumer's attitude towards advertising is one of the influential indicators of advertising effectiveness

Mackenzie and Lutz (1989) because consumer's cognitive ability towards the advertising are reflected in their thoughts and feelings and subsequently will influence their attitude towards advertising

Alwitt and Prebake 1992; Mackenzie and Lutz 1989 it influences attitudes toward a specific ad, an important antecedent of brand attitudes

Tsang, Ho, and Liang (2004) also found that consumers have generally negative attitudes toward mobile advertising unless they have specifically consented to receive the advertising 


\section{Macrothink}

messages

Kotler (2000) further explains that the attitude is the personal feelings of emotions or attached with any action about some idea or object.

Bauer and Greyser, (1968) considering the mobile marketing industry, attitude towards advertising is the audience behavior towards the advertising.

Beatty et al (1985)Values are the basis of actions, attitudes, and judgments related to advertising as well as other aspects of social life.

Ducoffe $(1995$, p 1) "may serve as an index of customer satisfaction with the communication products of organizations".

Schwartz and Bilsky (1987) A value is a "belief about some desirable end-state that transcends specific situations and guides selection of behavior"

MacKenzie and Lutz (1989, p 54) An attitude toward advertising is defined as a consumer's "learned predisposition to respond in a consistently favorable or unfavorable manner toward advertising in general"

Iacobucci and Churchill (2010) has a major impact on their behavior

Houston and Gassenheimer (1987) Exchange, the central concept in marketing, involves the passing of value to each party

Ducoffe (1995) an advertising message can be viewed as a potential communication exchange between advertiser and consumer

Ducoffe (1996) the value of any advertisement is evaluated against this criterion.

Mayer (1991) with the great advances in communication technologies that are expected, consumers may gradually pay for advertising they prefer and screen out the rest

Ducoffe (1996) one would expect that advertising that lacks value is likely to have a negative effect that will contribute to the formation of negative consumer attitudes toward advertising

Barnes and Scornavacca (2004, p. 133) "dynamic boundary produced by the combination of one's personal preferences"

Kautonen et al., (2007) without the explicit permission from the customer it is not possible to carry out mobile marketing

Kumar (2005) the current scenario and focus on past or present for example quality of life in a community or customer attitudes towards any marketing activity. 